\title{
EFFECT OF PARENTING STYLES ON PRE-SCHOOL AGE CHILDREN'S EMOTIONAL INTELLIGENCE OF TK ( KINDEGARTEN) MUSLIMAT NU 1 TUBAN
}

\author{
Kholifah \\ PG PAUD, FKIP, Universitas PGRI Ronggolawe, Tuban, Indonesia
}

\begin{abstract}
In recent years many people increasingly violates the norms, harms others, and not able to respect others. These behaviors are indication that they do not have emotional intelligence. Emotional intelligence is the ability to manage and control emotions. Emotional intelligence is needed to achieve success in all walks of life which is full of challenges. This ability should be instilled in children from an early age to be firmly entrenched and animate the child's behavior. The family is the smallest social group, first and foremost where the child learns anything, through habituation and modeling. Parenting style is the responsibility of the family, as it can affect in shaping the child's behavior. The problem is whether parenting can have an effect on the emotional intelligence of pre-age school children and what kind of parenting can influence the emotional intelligence of pre-age school children in kindergarten of NU I Tuban. The study aims to describe the influence of parenting styles to emotional intelligence of pre-age school children and to describe which kind of parenting can be more affecting on emotional intelligence of pre-school age children of TK NU I Tuban. The type of this research is quantitative, with the total population of 67 students. The researcher determined 40 students as sample by purposive sampling. This research uses data collection method including questionnaire that measure parenting style, and emotional intelligence of pre-school age children as well as observation, interviews, and documentation. Analysis of statistical data using multiple linear regression SPSS program. The result of this research is $\mathrm{F}$ count $>\mathrm{F}$ table $(33,144>2,641)$ and significance $<0,05(0,000<0,05)$, it means that emotional intelligence of pre-school age children can be influenced together by four kinds of parenting style ( X1, X2, X3, X4). $\mathrm{Y}^{\prime}=51,959+0.016 \mathrm{X} 1+$ $0,199 \mathrm{X} 2+0,184 \mathrm{X} 3+0,293 \mathrm{X} 4$. It reveals that the most influence between four parenting styles is parenting style of emotion coach (X4).
\end{abstract}

Keywords: Parenting Style, Emotional Intelligence

DOI: $10.7176 / \mathrm{JEP} / 10-2-13$

\section{Introduction}

Family is the initial, first and main environment of the children, therefore the family must be fully aware of it. Parents have a very significant and decisive role for children. Through advice and guidance, parents will be able to determine the children's development and future. Many factors influence the development of children's behavior, and one of these factors is parenting style or the style of parents in parenting. Parenting is the attitude and behavior of parents in caring for their children. Although this style will change as the children grow, and the expansion of the milieu, the style core tends to remain. This is why the relationship between mother father and other family members in parenting is an important element for children's development, it can be in the form of style being a parent or other forms of parenting for their children.

Living everyday life that is "successful" today does not rely solely on intellectual intelligence. This is based on the results of research that provides a description that a high level of intellectual intelligence is not the only cornerstone to be able to survive and develop themselves. Emotional intelligence is something that must be possessed by every human being, in addition to intellectual and spiritual intelligence. Emotional intelligence is a person's ability to manage his emotions or control his emotions. With the possession of emotional intelligence, people will be able to respond and react to an stimulus in accordance with its portion or not excessively. The ability to "think" and "feel" will go hand in hand and balance, so that humans behave tend not to harm others. If someone has emotional intelligence, it means he already has the asset to achieve success. However, what happens to the lives of the people around us is the increasing number of crimes, actions that harm others, and unpleasant actions, robbery, rape, corruption, slander, irresponsible behavior, etc. It ptoves the reality that people are less able to control themselves or unable to manage his emotions

Pre-school age children as the nation's next generation must be qualified, so that in the future these children can 
become successful children in life. Parents and teachers must be able to realize these noble hopes by providing one of life's important provisions, namely emotional intelligence. Emotional intelligence can be embedded firmly and animates children's behavior, if parents instill it from an early age. Guiding children to have emotional intelligence is not an easy thing, because it needs to be pursued seriously. These efforts can be through the application of the parent style / parenting style. The research of Hidayah, R., Eka Y., Yulian W. U. (2013), resulted that there is a positive correlation of 0.909 and has a significance value of $0.000(\mathrm{p}<0.05)$, it means that there is a relationship between parenting styles and emotional intelligence of pre-school age children. Another similar study was the research of Pujiharti, I. and Mathilda, R.H., which resulted a Chi Square test of 6.359 with a X2 table value of 3.84. This means that X2 tables are smaller than X2 results, which indicates there is a relationship between parenting and emotional intelligence of pre-school age children. With this background, it seems very important for everyone to have emotional intelligence. On this basis the researcher conducted a study under the title "Effect of Parenting Styles on Pre-school Age Children's Emotional Intelligence of TK Muslimat NU I Tuban

\section{Literature review}

\section{Parenting}

\section{a. Definition}

According to Susanto (2015: 26), parenting is a pattern of interaction between children and parents as long as the child is in caregiving. In the parenting process, in addition to how parents treat children, it is also about parents' ways of educating, guiding, instilling discipline, and protecting children. Children are expected to be individuals who have maturity in accordance with the norms that apply in society in general .The task of caregiving includes the attitudes of parents towards their children, it involves how rules are applied, the ways in giving gifts and punishments, the way parents show authority and also how parents pay attention and responses to their children. So parenting is the way parents carry out nurturing for their children as an obligation that is not replaced by anyone, and forms of responsibility as the smallest institution of a society. In other words it can be said that parenting is parents' style of being parents.

\section{b. Types of Parenting.}

Regarding the type of parenting, Susanto (2002: 26) divides parenting into three trends, namely:

1) Authoritarian, characteristically assertive, punishing, lacking affection, lack of sympathy. Parents like to force their children to obey their values, and try to shape children's behavior according to their parents' behavior patterns, and tend to curb children's desires. Parents do not encourage children to be independent, they tend to give responsibilities that are too burdensome for children, and children have very limited rights.

According to Stewrt \& Koch (1983) in Susanto (2002: 26) the characteristics of authoritarian parents are always rigid, punitive, do not show feelings of affection and are not sympathetic. They always see children in terms of adherence to parental authority, tragically the attitude of authoritarian parents has a tendency to give punishment, especially corporal punishment.

The effects of authoritarian parents generally shape the behavior of a confused child, easily offended, whose characteristics are fear, nervous, aggressive and preffering solitude, gloomy and sad. Children are unsympathetic, dissatisfied, easily suspicious, lack of initiative, easy to be nervous, hesitant, disobedient, like to oppose the authority of parents, possibly become timid or too obedient (Susanto, 2002: 27).

2) Democracy, according to Susanto (2002: 28) parents who have parenting democrats are usually warm and close to children, mention clear standards to their children, apply and communicate rules strictly and clearly, do not like disobidient children, do not hesitate to apply physical punishment within certain limits consistently if the child makes mistakes repeatedly, and gives rewards when getting achievements and giving support if the child conducts constructive activities.

The effects of democratic parents generally shape the behavior of energetic and friendly children who have characteristics; independent, have high energy, able to control themselves, cheerful, friendly, easy to work with other people (both with peers or those who are more mature), have the ability to deal with and overcome the possibility of stresses.

3) Permissive, is a parenting style that tends to give freedom to children with very loose control, children are left to their own will, as if to spoil children excessively, always meet the children's requests, and parents do not regulate much. Parents do not clearly communicate the rules to children, inconsistently instill discipline, but 
are warm enough for their children (Susanto, 2002: 29). According to Hurlock (1982) permissive parenting is characterized by lack of control, guidance for children is not much done. They are kind of loose and free parents.

The effect of permissive upbringing will make children who behave wildly without control, ignorant, children free to act at will, rarely communicate, children will not obey and oppose the rules, lack confidence, lack of self control, tend to be aggressive, impulsive and have no purpose. Other effects are under-developed children, dependency and unhappiness, chaotic personality, always suspicious of others, and difficult to cooperate with, have no sympathy for parents, emotions are unstable, always feel dissatisfied.

Hurlock (1974: 355) parenting styles of children consists of four types that are bipolar in nature, meaning pairs and opposites, namely, 1) tolerant and intolerant; 2) permissive and strict; 3) allow and be involved; 4) cold relationship and warm relationship.

According to Syaodih (1999: 26-31) a positive parenting style on pre-school age children is based on:

1) Parenting of intimacy that is, based on love, and warmth, and proximity between one another. Mother would approach her children by displaying motherhood while guiding her. Mother's feelings are not involved and are not affected even though they live. In guiding need not only maternal instinct but also requires very high awareness. Excessive love affords a sense of indulgence. On the contrary, less affection causes the relationship to be cold, arid, lonely, because of lack of love. What should be benchmarked by parents is love based on responsibility and demanding responsibility.

2) Parenting with the principle of caring, that is, based on the principle of caring (attention, interest, sincerity). Attention is given to the child about what is needed, what is felt, hearing and answering questions with reasonable meaning according to the age of the child. A reasonable personality development will be obtained by the child if parents show care for their children by always giving guidance to their children.

3) Parenting with the principle of freedom, that is, based on the principle of freedom, children are given freedom without hesitation to choose, and express their opinions. In guiding their children, parents always stimulate their children to dialogue without hesitation, direction, and accept freedom with full responsibility. Freedom given is not without limits but there is still control. This means not freedom without foundation and grip, but freedom on the basis of provisions. As a human being has duties and responsibilities towards his creator, as a consequence of attachment to the laws of life.

4) Parenting with the principle of independence. Initially parents do not hesitate to direct, encourage, get used to, so that children do it themselves. Gradually the child becomes trained / accustomed, over time the child will do it himself. The implementation of this pattern is not easy to run well while actually it is an ideal parenting. Parents still help often what children do because they do not have the heart, whereas in fact children are still able to do it.

5) Parenting with the principle of discipline, it is a parenting with rules attachment.. According to Abdullah (in Susanto, 2002) discipline is a set of planned activities or exercises needed to achieve certain goals (positive discipline). Discipline is a punishment for unwanted behavior (negative discipline). The aim is to avoid unwanted behavior, help individuals to understand what is needed to achieve goals and to encourage people to maintain and obey the practices or rules that have been developed. The principle of guidance must be carried out in instilling discipline as something fundamental to children. The principle of guidance must be carried out in instilling discipline as something fundamental to children.

6) If parents instill discipline in children that goes through a good relationship, then this is an essential step in guidance, Furthermore, the child can introspect about why there is a violation, what must be done, and what the consequences for him or for others.

7) Parenting with realistic principles, parenting that is oriented to reality. Children are taught to be able to live by accepting things as they are, something that is in accordance with their abilities, receiving facilities with existing conditions. Parents are required to state something honestly, not to find excuses to make children happy

8) Parenting with the principle of stable emotions. In parenting, parents should not show negative emotions (full of tension, anger, sadness, anxiety, quick offense) and other similar attitudes. As parents, they must continue to learn to be able to control their emotions, so they are ready to face the kinds of behaviors and willingness of their children

Lazarus (1876: 242) revealed the type of parenting parents towards their children, described as ignoring, overprotective, possessing as they wish, accepting, warm, hostile, rejecting, and others (parental attitudes toward the child can be described as neclectful, overprotective, possessive, rejecting and so on).

Gottman and DeClaire (1999: 43) divide the style of parenthood (parenting) in four styles, namely: 
1) Dismissing parents style, parents are accustomed to directly solving children's problems or cleaning up all children's pain, not first asking what the child feels, trying to avoid unpleasant feelings in children, children cannot automatically feel what they feel but people parents who teach that feeling, minimize / underestimate children's sadness and children's problems, cover it up and throw it away to be forgotten or by diverting, parents feel afraid children will be emotional and lose control. The effect of this parents style ; They learn that their feelings are wrong, inappropriate, not valid. They may learn that there is something inherently wrong with them because of the way they feel. They may have difficulty regulating their own emotions

2) Dissaproval parents, parents are strikingly critical and do not empathize. They tend to be suspicious of children's emotional experiences, do not understand children but are more likely to pay attention to behavior around children's emotions, take advantage of trivial situations before determining actions, fear, difficult to control emotion, parents do not let the children to experience their emotions nor deal effectively with the child is not ready to face challenges. As a result of the disapproving parents' style; they learn that their feelings are wrong, inappropriate or illegitimate, 5hey may learn that there is something inherently wrong with them because of the way they feel, they may have difficulty regulating emotions (same as type ignoring).

3) Laissez Faire parents (Latin, meaning leave it alone), empathetic parents (whatever may be), let the child express emotion as long as "our work is finished", tend to be unskillful not willing to guide how to deal with negative emotions, little awareness of how help children to learn from emotional experiences, unsure of what to teach, like to accept children's reactions without giving, children cannot calm themselves / overcome emotions, do not provide guidance on managing emotions, let children release their emotions inappropriately / free emotional expressions. As a result of parents who laissez faire are: children do not learn to regulate their emotions, children has difficulties in concentrating, having friendship, or associating with other children.

4) Emotional coach parents, in carrying out the role as an emotional coach requires interaction in five steps, namely: 1) aware of the emotions of his child; 2) recognizing that emotion as an opportunity for closeness and couching; 3 ) listen empathetically and strengthen children's feelings; 4) help the child label the emotion he or she is feeling,

Parents with this style are able to accept the child's feelings and do not ridicule and do not underestimate, guide the child in the world of emotions, go further than accepting and fixing the limits of inappropriate behavior, teaching children about how to regulate feelings to find expressions the right expression, and solving problems, taking the positive side of something that we think is negative, giving an appreciation of the child's emotionalemotion statement and reacting with good ways, encouraging children's emotional honesty, being able to stop harmful behavior and directing back to activities or expressions that are not detrimental, not protecting the child against unpleasant emotions so that the child gets experience and how to regulate it, parents do not immediately deal with the difficulties / problems of the child, parents do not hesitate to show their emotions in front of children, willing to apologize to children if they get wrong.

Therefore emotional coaches parents have advantages for their families, including: 1) parents are consistent and responsive to their children if the feeling is still at a low level of intensity. This means that children do not need to raise their emotions to get parents concern. Eventually the child will get the impression that their parents pay attention, understand, and empathize in their lives. They don't need to vent their anger to get attention from parents 2) If the children are accustomized since their early childhood. They will be able to console them self and stay calm without getting inner pressure and this causes no wrong action, 3) Parents do not deny their emotions so that they reduce opposition, because there are clear and consistent boundaries and messages about everyday behaviors, so that emotional coaches parents create emotional bonds between children and parents to be strong, therefore the child will be responsive to the requests of parents.

Children see parents as their allies, they want to make their parents happy and do not want to make them disappointed. The effect of emotional coaches parents for children includes children learn to trust their feelings, regulate their own emotions, solve problems, have high self-esteem, study well, and have good socialization

\section{Emotional Intelligence}

a. Understanding

In the reality of everyday life we often find people who are less precise in interpreting the word emotion. Emotions are often interpreted as angry or identified with anger (Wiyani, 2014: 21). So that angry people are called emotional people. What if the nature (angry) compared with emotional intelligence, it means the intelligence of someone in managing their feelings so as to lead to positive behaviors, then it will be increasingly 
not comparable.

Emotions in the most literal meaning are defined as every activity or upheaval of thoughts, feelings, passions of any great or overflowing mental state. Language emotion means an overflow of feelings that develops and recedes in a short time (Wiyani, 2014; 21). Emotions are feelings that are fluctuating meaning a state of feeling that is elevated and not mediocre towards something.

Feeling is a state of someone who responds to something that is lived with feeling like or dislike. Emotions can also be a state and a person's psychological reactions, such as excitement, sadness, renewal, love, and anger (Alwi, et al .: 2002). In language, the emotions that surround a person at a certain time. There are feelings of pleasure, love, love, etc. are positive feelings. Whereas hate, anger, sadness, disappointment, fear, anxiety, etc. are negative feelings..

Aliah B. Purwakania divides emotions into two types, namely: 1) Primary Emotion, is a basic emotion that has been biologically present in humans from the beginning, a factor that was brought to birth, such as pleasure, sadness, fear, and anger; 2) Secondary emotions, the existence of this emotion is more complex than primary emotion, which contains self-awareness or self-evaluation whose development depends on one's cognitive or intellectual development. So the notion of emotion can be summed up as an individual feeling, both positive and negative as a response to a situation that surrounds it, because of the relationship between humans and their environment or a group.

According to Wiyani (2014: 98) the word " intelligence", etymologically comes from the word "smart" which means that the mind is perfectly developed (to think, understand, understand, etc). Emotional intelligence can be interpreted as the ability of an individual to manage his feelings when he relates to himself, his fellow human beings, and other creatures in the environment (Alwi, et al .: 2002)

In other words emotional intelligence is a person's ability to control himself. Daniel Goleman (2003) reveals that humans have what is called inner control. According to him, when humans have to make decisions, caution becomes the purest human senses to understand what is felt right or wrong and provide important information that they should not ignore, otherwise it will cause regret later. Inner voice is often known as the conscience, conscience will not lie, so humans who have emotional intelligence are those who are able to keep their conscience. Furthermore, according to Seto Mulyadi, emotional intelligence is the ability to recognize self emotions, motivate, recognize the emotions of others, and build relationships with oneself or others, and his surrounding social environment.

Likewise with women who have emotional intelligence, their characteristics are as follows; 1) tend to be assertive; 2) able to express feelings directly; 3) view themselves positively; 4) their lives give meaning to them; 5) sociable and friendly; 6) express their feelings fairly (not explosively then regret it); 7) able to adjust to the burden of stress; 8) the stability of their relationships makes it easy for them to accept new people; 9) quite comfortable with herself so that she is always cheerful, spontaneous, and open to sensual experiences; 10) rarely feel anxious or guilty, or moody.

People who have high emotional intelligence will usually be more humanistic. The main elements of emotional intelligence that make individuals more humanist according to Goleman (2003) include; 1) selfawareness / being able to recognize yourself; 2) personal decision making; 3) managing feelings; 4) dealing with stress; 5) empathy; 6) communication; 7) open up; 8) understanding / identifying patterns of emotional life on the positive side, strengths and strengths; 9) personal responsibility; 10) firmness / without anger; 11) group dynamics; and 12) resolve conflicts.

b. Emotional intelligence in pre-school age children

The existence of emotional intelligence should be possessed by all humans and all ages, including preschool age children. If it is understood more deeply, actually the charge of emotional intelligence is something that is not easy to have, because it is related to a personal emotional atmosphere. So in the target of achievement,Someone can be said whether " he have had emotional intelligence or not yet", or "even he has no emotional intelligence", extremely related to the age level of child development.

The emotional intelligence in pre-school age children in Wiyani's opinion (2014: 88) includes four components, namely; 1) the ability to recognize emotions themselves; 2) ability to regulate emotions themselves; 3 ) the ability to recognize the emotions of others; and 4) the ability to manage the emotions of others. Whereas according to Goleman (2003) there are seven main elements of early childhood emotional intelligence, namely; 1) belief; 2) curiosity; 3) intention; 4) self control; 5) linkages; 6) communicative skills; and 7) cooperative.Urgensi kecerdasan emosi pada anak usia dini. 
Emotional intelligence has an important meaning for pre-school age children, because pre-school age children is a creature that is just learning to walk life and the task of its development is learning anything. In the learning process there needs to be sufficient assets, so that learning goals can be achieved. The learning process is not something that is immediately made and successful, this requires effort and struggle. Children will easily reach their efforts if they have emotional intelligence. According to Wiyani (2014: 92) there are something to do with emotional intelligence : 1) Can be used as a means of controlling oneself to avoid actions that harm themselves and other people and beings around them; 2) Can be used as a selection tool for parents to recognize the talents and interests of pre-school age children; 3) Can be used as asset to develop their potential; 4) Can be used as capital to foster his leadership in any field; 5) Can be used as a tool, to avoid excessive anxiety and fear, tendency to be alone, feeling nervous and inferior; 6) Can be used as an inner driver in empathizing with others.

\section{Method}

The population of this study were students of TK Muslimah NU I Tuban who numbered 67 students, while the sample obtained was 40 students with sample determination using purposive sampling technique. Data collection techniques used include questionnaire methods, interviews, observation, and documentation. The observation method is done to get additional data about the behavior of students and parents at school. The documentation method is carried out to obtain data on students, teachers and schools. Whereas interviews with the teacher council were conducted to obtain additional information and the validity of the research data. The questionnaire method consists of two parts, namely a questionnaire about emotional intelligence and the parenting style of students' parents. The questions in the emotional intelligence questionnaire were prepared based on the concept Wiyani's concept(2014) which consisted of four aspects, and Goleman (2003) which consisted of seven aspects. Questions in the questionnaire about emotional intelligence in early childhood initially consisted of 40 questions. After testing the validation, 10 questions that fall which have the coefficient $r$ in the test of data validity $<0.300$. So, the item questions used in the study are as many as 30 items, which consist of favorable items. The 30 items in question have fulfilled the reliability test. So that the questionnaire about children's emotional intelligence has been valid and reliable to use in this study.

Questionnaire about the style of parents / parenting style, the question items refer to the opinions of John Gottman and Joan DeClaire (1999). Item questions about the style of parents / parenting style, do not need to be tested for validity and reliability because psychology laboratories have been tested and, they are standard questions. Four style of parents / parenting styles are: 1) ignoring; 2) dissaproving: 3) laissez faire; and 4) emotional cough. The questionnaire was filled out by students' parents as kindergarten students could not read.

The data analysis technique used is multiple linear regression. Before conducting a regression analysis, the data that has been collected is a classic assumption test. The classic assumption test consists of normality test, autocorrelation, multicollinearity, heteroscedasticity

\section{Results And Discussion}

\section{Results}

Classical Assumption Test, according to Ghozali (2013), the classic assumption test consists of autocorrelation normality, multicollinearity, and heteroscedasticity. The following is an explanation of the classic assumption test in this study.

1) Normality Test

Normality test aims to test the population distribution of each variable whether normal or not. The results of the data normality test are significance (Asymp Sig) of 0.175 (dismissing parent), 0.169 (disapproving parent), 0.053 (laizestaire parent), 0.126 (emotional coach parent) and 0.143 (child emotional intelligence). As the significance is $>0.05$, it means that the distribution for each variable is normal.

\section{2) Autocorrelation Test}

Autocorrelation is a correlation between members of observations arranged according to time and place. A good regression model should not occur autocorrelation. The test method uses the Durbin-Watson Test (DW test). If 'd' is the Durbin Watson value, there is no autocorrelation if $\mathrm{du}<\mathrm{d}<(4-\mathrm{du})$. Based on the Durbin Watson table $\alpha=$ $5 \%, \mathrm{~N}=40$, and $\mathrm{k}$ (independent variable) $=4$, then the values $\mathrm{du}=1.7209$ and $(4-\mathrm{du})=22791)$. The value of the autocorrelation test is the Durbin Watson value of $2,193(1,7209<2,193<2,2791)$, it can be concluded that there is no problem with autocorrelation. 


\section{3) Multicolonity Test}

The multicollinearity test is done by looking at the tolerance and inflation factor (VIF) values in the regression model. Variables that cause multicollinearity can be seen from tolerance values that are smaller than 0.1 or VIF values that are greater than the value of 10 (Priyatno Duwi, 2009). The following table 1 is the result of the Multicolonity Test.

Table 1. Multicollinearity Test Results

\begin{tabular}{llll}
\hline \multirow{2}{*}{ Model } & \multicolumn{2}{c}{ Collinearity Statistics } \\
\cline { 2 - 4 } & Tolerance & VIF \\
\cline { 2 - 4 } & (Constant) &, 226 & 4,418 \\
\cline { 2 - 4 } & Dismissing &, 359 & 2,789 \\
\cline { 2 - 4 } & Disapproval &, 480 & 2,082 \\
\hline Laizestaire &, 337 & 2,966
\end{tabular}

Dependent Variable: Emotional Intelligence of Pre-School Age Children

From Table 1 it can be seen that the Tolerance value of the four variables is more than 0.10 and VIF is less than 10. Therefore, it can be concluded that there is no multicollinearity between independent variables.

\section{4) Heteroscedasticity Test}

Heteroscedasticity is a residual variant that is not the same in all observations in the regression model. Good regression should not occur heteroscedasticity. The Heteroscedasticity test in this study uses test using the pattern of dots on the regression chart. If there is a certain pattern, such as the existing points form a certain pattern that is regular (wavy, widened, then narrowed), then heteroscedasticity occurs. If there is no clear pattern, such as points spread above and below the number 0 on the $\mathrm{Y}$ axis, there is no heteroscedasticity. Figure 1 below is the result of heteroscedasticity test.

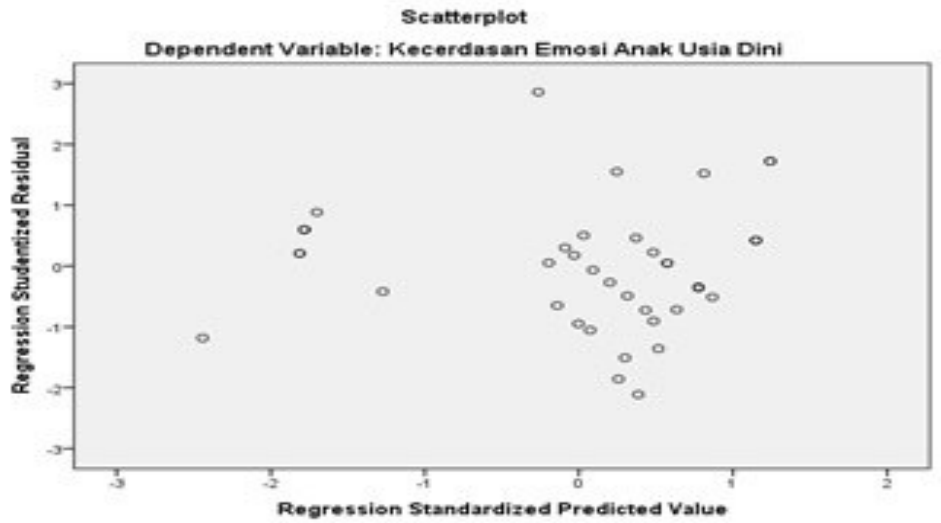

Figure 1. Scatterplot graph

5) Multiple Regression Analysis

After the classic assumption test is done, it is concluded that the regression model has fulfilled. The results of multiple linear regression analysis show $F$ count $>F$ tabe $(33,144>2,641)$ and significance $<0,05(0,000<0,05)$, then $\mathrm{HO}$ is rejected means, the four parenting styles such as dismissing parent, diapproval parent, laissez faire parent, and emotion coach together influence the emotional intelligence of pre-school age choldren at the TK Muslim NU I Tuban. The complete results of multiple regression analysis can be seen in Table 2 below. 
Table 2. Multiple regression analysis

\begin{tabular}{|c|c|c|c|c|c|c|}
\hline & & \multicolumn{2}{|c|}{ Unstandardized Coefficients } & $\begin{array}{l}\text { Standardized } \\
\text { Coefficients }\end{array}$ & \multirow[b]{2}{*}{$\mathrm{t}$} & \multirow[b]{2}{*}{ Sig. } \\
\hline \multicolumn{2}{|c|}{ Model } & $\overline{\mathrm{B}}$ & Std. Error & Beta & & \\
\hline \multirow[t]{5}{*}{1} & (Constant) & 51,959 & 9,220 & & 5,635 & $\overline{0}, 000$ \\
\hline & Mengabaikan & ,016 & ,001 & ,023 & 001 & 999 \\
\hline & $\begin{array}{l}\text { Tidak } \\
\text { Menyetujui }\end{array}$ & 199 & 079 & ,326 & 2,526 &, 016 \\
\hline & Laizestaire & , 184 & 075 & 275 & 2,466 & 019 \\
\hline & Pelatih Emosi & 293 & ,092 & 426 & 3,202 & 003 \\
\hline
\end{tabular}

a. Dependent Variable: pre-school age children's emotional intelligence

The table above describes the acquisition of the four parenting style, the greatest value is the value of the of emotion coach parent style, which is 0.293 meaning that among the four parents / parenting styles, the emotion coach style is the most influential on emotional intelligence of pre-school age children

\section{Discussion}

The results of the study show that, however the form of the style of being a parent / parenting style will influence the emotional intelligence of pre-school age children. Parents are the ones who are most responsible for the family as absolute power holder to control the domestic or family life. Children accept the bad and good from their parents, parents as models in all behaviors. Children are care for in ways that make children feel comfortable, safe, full of enthusiasm, and feel their existence recognized. Many parents still have an inappropriate understanding, that they are only small children who do not know anything, cannot feel anything, do not have any needs. As a result they are small creatures that are among us that must be regulated and controlled as adults wish. In some cases it can be considered as such, but in other cases it does not have to be, especially in matters of the child's emotional life.

Educating children's emotions has become a parent's duty that cannot be considered trivial and light. In their duties as parents, the dynamics in the family need to be controlled through proper and healthy interactions. Interaction is intended primarily in terms of emotional interactions between parents and their children. Emotional interactions between parents and their children can have a greater influence on the long-term welfare of a child. The emotional interaction of children with parents is very important, the right affection between family members becomes the basis for the emergence of values and nurture moral people.

Life is getting more and more of challenges, inevitably children must face it someday . Intellectual intelligence alone is not enough to deal with these challenges, the balance needed is to have emotional intelligence. With intelligence, human emotions are able to control their abilities, feel what they senses, adapt to environmental demands in an intelligent way. Being able to recognize the presence of others in a roomy, wise, able to respect others, not imposing, and not demeaning. Even said to achieve success in living life, can be owned by people who have emotional intelligence. Humans who have emotional intelligence can regulate their own emotions, maintain their enthusiasm, be able to calm themselves, have confidence, understandingly to act, calm / stable, capable of controlling themselves, success in collaboration, and so on.

Quoted from the opinion of Goleman (2003), many people who have high intellectual intelligence even become subordinates of people who have high emotional intelligence. Even leaders who have low intellectual intelligence turn out to have high emotional intelligence. Emotional intelligence will usually appear in his ability to empathize with others, show his tenacity, personal ambitions, and understand clues. Furthermore, Daniel Goleman (2003) said, in determining life success, the highest intellectual intelligence only contributed $20 \%$. While $80 \%$ is the other intelligence, including emotional intelligence. Robert K. Cooper and Ayman Sawaf (in Efendi, 2005) emphasize that today the relationship between intellectual intelligence and life success is only $4 \%$, meaning that more than $90 \%$ of life success is related to other forms of intelligence, such as emotional intelligence.

According to Armstrong (2002), people who have high intellectual intelligence usually have difficulty in getting along, not knowing themselves, having problems with impulse control, or emotional tuna (difficulty 
determining what is felt at some time). In living a larger life experience difficulties, even though their school performance is brilliant). So it can be concluded that emotional intelligence is very important for every human being to live life.

As parents, they must strive to be able to form emotionally intelligent individuals through appropriate parenting styles / patterns. That certainly requires a strong intention, sincere selflessness, and full of responsibility. A psychologist and author of Emotional Intelligence Daniel Goleman (1995) says that family life is our first school to study emotions. In this school not only work through things that parents do and say directly to their children, but also in the examples they give to deal with their own feelings and things that happen between husband and wife. Some parents can be gifted emotional teachers, but some are not like that (Goleman, 1995).

If humans do not have emotional intelligence, commonly they become more anxious and easily angry, more moody and lackluster, more depressed and lonely, easier to obey their hearts / passions, tend to always be disobedient, and so on. The occurrence of many crimes in the environment around us, is an example of the low emotional intelligence of our society. We have to contemplate the obvious / blatant "widespread" depravity of emotions. Examples at the lowest level are in children, children who cannot work together, this ability is indeed not easy for children to do, because children have high selfishness. Whereas in working together, he must know when he must give in, must take turns, when he must defend his rights, or help his friends, etc. Then cases at the youth level for example; children who are easily discouraged because they can not achieve what they want, lazy / not excited, hurt their friends and even kill. Whereas an example at the level of adults, someone who has the heart to kill his coworkers because he is very offended with his statemens that humble themselves, rob, corruption, and so on.

The ability of emotional intelligence is not easy to have, it must be trained early, because at this time emotional intelligence must have become an important tool for humans to lead a successful life. But are parents able to do it? There is a belief that parents must have that they must be able to, if parents want to implement it will certainly be achieved. Unlike intellectual intelligence, it is something that is owned by innate factors or genes / offspring and cannot be trained. If we go back to its function, the family is the smallest form of society that is responsible for the generation of the nation. So through the family emotional intelligence of children can be trained and formed early on through the application of the style of being a parent or parenting parents.

\section{Conclusion}

The results of this study indicate that $\mathrm{F}$ count $>\mathrm{F}$ tabe $(33,144>2,641)$ and significance $<0,05(0,000<0,05)$, then $\mathrm{HO}$ is rejected means, the four parenting styles such as dismissing parent, diapproval parent, laissez faire parent, and emotion coach together influence the emotional intelligence of pre-school age choldren at the TK Muslim NU I Tuban.. Among the four types of parenting, the type of emotion coach is the one who has the greatest influence on the emotional intelligence of pre-school age childrenat the TK Muslim NU 1 in Tuban. Judging from the regression equation resulting from the following statistical analysis, $\mathrm{Y}^{\prime}=51,959+0,016 \mathrm{X} 1+$ $0,199 \mathrm{X} 2+0,184 \mathrm{X} 3+0,293 \mathrm{X} 4, \mathrm{X} 4$ which is the type of emotion coach produces 0.293 , which means that every increase in Parental Parenting Type Emotion couch of 1, then Emotional Intelligence of Early pre-school age children also increased by 0.293 .

From the results of research on parenting toward the emotional intelligence of pre-school age children of the Muslimat NU I Tuban kindergarten described above, the parents of the kindergarten students:

1) Should pay attention to the needs of their children.

2) Always establish a reasonable and comfortable relationship with their children.

3) Always be an example or model for their children.

4) Must maintain the atmosphere in their household.

5) Be able to observe and be sensitive toward changes that occur in their children

\section{Acknowledgement}

Thank you to the Head of the NU 1 Tuban School for the opportunity given to conduct the research

\section{Reference}

Amstrong, Thomas. 2002. Setiap Anak Cerdas: Panduan Membantu Anak Belajar Dengan Memanfaatkan Multiple Intelligence-nya. Terj. Rina Buntaran. Jakarta: Gramedia Pustaka Utama. 
Amstrong, Thomas. 2013. Kecerdasan Multiple di dalam Kelas. Terjemahan: Dyah Widya Prabaningrum. Jakarta: Indeks.

Efendi, Agus. 2005. Revolusi Kecerdasan Abad 21: Kritik MI, EI, SQ, AQ dan Successful Intelligence atas IQ. Bandung: Alfabeta.

Ghozali, Imam. 2013. Aplikasi Analisis Multivariate Dengan Program SPSS. Edisi Ketujuh. Semarang: Badan Penerbit Universitas Diponegoro.

Goleman, Daniel, 1995. Emotional Intelegence. New York: Bantam.

Goleman, Daniel. 2003. Kecerdasan Emosional: Mengapa EI lebih Penting daripada IQ. Terjemahan: T. Hermaya. Jakarta: Gramedia Pustaka Utama.

Gottman, John dan DeClaire, Joan. 1999. Kiat-kiat Membesarkan Anak yang Memilik Kecerdasan Emosional. Jakarta: Gramedia.

Hasan, Aliah B. Purwakania. 2006. Psikologi Perkembangan Islami: Menyingkap Rentang Kehidupan Manusia dari Prakelahiran hingga Pascakematian. Jakarta: Rajawali Perss.

Alwi, Hasan dkk. 2002. Kamus Besar Bahasa Indonesia. Jakarta: Balai Pustaka.

Hidayah, R., Eka Y., dan Yulian W.U. 2013. Hubungan Pola Asuh Orang Tua Dengan Kecerdasan Emosional Anak Usia Prasekolah (4-6 tahun) di TK Senaputra Kota Malang. Jurnal Keperawatan ISSN 20863071.Diakses tanggal 17 Februari 2018. http://ejournal.umm.ac.id.

Hurlock, 1974. Personality Development. New York: McGraw-Hill Publish-ing Co, Ltd.

Lazarus, Richard. 1976. Pattern of Adjustment. Tokyo: Mcgraw-Hill Kogakusha.

Priyatno, Duwi. 2009. 5 Jam Belajar Olah Data Dengan SPSS 17. Jogjakarta: CV. Andi Offset.

Pujiharti, I. dan Mathilda R.H. 2016. Hubungan Pola Asuh Orang Tua Dengan Kecerdasan Emosional Anak Prasekolah (3-6 tahun) di Raudatul Atfal (RA) Al-Muttaqin Jati Bening Baru Tahun 2016. Diakses tanggal 17 Februari 2018. http://uia.ac.id/

Susanto, Ahmad. 2015. Bimbingan \& Konseling di Taman Kanak-kanak. Jakarta: Prenadamedia.

Syamsu, Yusuf. 2005. Psikologi Perkembangan Anak dan Remaja. Bandung: PT Remaja Rosdakarya.

Syaodih, Ernawulan. 1999. "Peranan Bimbingan Guru, Pengasuhan Orang Tua, dan Interaksi Teman Sebaya terhadap Perkembangan Perilaku Sosial Anak”. Tesis. Bandung. Tidak diterbitkan. 